\title{
ANALISIS TAPAK EKOLOGI UNTUK ARAHAN PEMANFAATAN RUANG PULAU LOMBOK
}

\author{
Ecological Footprint Analysis for Spatial Use Directive of Lombok \\ Island
}

\section{Baiq Ahda Razula Apriyeni ${ }^{1}$, Kukuh Murtilaksono² ${ }^{2}$ Setia Hadi ${ }^{3}$}

Diterima: 18 April 2016 Disetujui: 6 Februari 2017

\begin{abstract}
Abstrak: Tujuan penelitian ini adalah 1) Menghitung nilai tapak ekologis di Pulau Lombok melalui pendekatan Supply (pasokan) dan Demand (permintaan) berdasarkan GFN (Global Footprint Network), Kesesuaian Lahan dan Rencana Tata Ruang Wilayah, 2) Mengevaluasi dan menilai ketiga pendekatan perhitungan nilai tapak ekologi, 3) Merumuskan arahan pemanfaatan ruang berdasarkan hasil perhitungan nilai Tapak Ekologi. Berdasarkan hasil perhitungan tapak ekologi dan biokapsitas dengan tiga pendekatan yang dilakukan, diperoleh hasil bahwa Pulau Lombok dikategorikan ke dalam tiga kategori wilayah defisit ekologi yakni: wilayah surplus (berdasarkan pendekatan GFN), wilayah surplus (berdasarkan pendekatan kesesuaian lahan), dan wilayah defisit (berdasarkan pendekatan terhadap RTRW). Dari tiga pendekatan tapak ekologi yang digunakan, pendekatan Rencana Tata Ruang Wilayah yang paling nyata untuk menggambarkan kondisi tapak ekologi di Pulau Lombok. Arahan pemanfaatan ruang berdasarkan tapak ekologi di Pulau Lombok adalah sebagai berikut: 1) Lahan pertanian perlu ditambahkan seluas 121.305 ha, 2) Lahan peternakan dikurangi seluas 181.031 ha, 3) Lahan perikanan ditambahkan lahan seluas 248.429 ha, 4) Lahan hutan perlu penambahan luasan sebesar 151.439 ha, 5) lahan terbangun perlu ditambahkan seluas 159.132 ha. 6) Lahan yang berfungsi sebagai penyerap karbon perlu ditambahkan lahan seluas 14.024 ha.
\end{abstract}

\section{Kata Kunci: tapak ekologi, biokapasitas, defisit ekologi, arahan pemanfaatan ruang}

Abstract: This study aims to 1) Calculate the ecological footprint in Lombok Island through Supply and Demand approach by GFN (Global Footprint Network), Land Suitability and Spatial Planning, 2) Evaluate and assess the three approaches to calculate the value of the ecological footprint, 3) Formulate the direction of spatial use based on the calculation of the ecological footprint. Based on the calculation of the ecological footprint and biocapasity by three approaches found that the results showed Lombok Island was categorized into three categories deficit ecological area: surplus territory (based GFN approach), surplus territory (based on land suitability approach), and deficit area (based on Spatial Planning approach). Of the three approaches of ecological footprint used, Spatial Planning approach was the most realistic to describe the condition of the ecological footprint in Lombok Island. As for the direction of spatial use based on the ecological footprint in Lombok Island was as follows: 1) Agricultural land needs an additional area of 121,305 ha, 2) Farm land area is reduced by 181,031 ha, 3) Fishery land needs an additional area of 248,429 ha, 4) Forest land needs an additional area of 151,439 ha, 5) Developed land needs an additional area of 159,132 ha, and 6) Land which serve as an sequestration needs an additional area of 14,024 ha.

Keywords: ecological footprint, biocapacity, ecological deficit, spatial use directive.

\footnotetext{
${ }^{1}$ Program Studi Ilmu Perencanaan Wilayah, Fakultas Pertanian, Institut Pertanian Bogor

${ }^{2}$ Departemen Ilmu Tanah dan Sumberdaya Lahan, Fakultas Pertanian Institut Pertanian Bogor

${ }^{3}$ Departemen Arsitektur Lanskap, Fakultas Pertanian Institut Pertanian Bogor
} 


\section{PENDAHULUAN}

Pulau Lombok merupakan salah satu pulau dari dua pulau besar yang terdapat di provinsi Nusa Tenggara Barat, terdiri dari empat kabupaten dan satu kotamadya. Luasnya mencapai lebih kurang 4.738,14 $\mathrm{km}^{2}$. Pertumbuhan penduduk di Pulau Lombok menunjukkan peningkatan di tahun 2013 penduduknya berjumlah 3.228.654 jiwa, dan pada tahun 2015 meningkat menjadi 3.352.988 Jiwa (BPS NTB, 2015). Diperkirakan pada tahun 2035 jumlah penduduk Pulau Lombok terus meningkat menjadi 4.573.319 jiwa. Dengan laju pertumbuhan penduduk sebesar 1,56 persen setiap tahunnya dalam kurun waktu 20 tahun mendatang jumlah penduduknya bertambah sebesar 1.222 .331 jiwa. Tingginya pertumbuhan penduduk di Pulau Lombok berbanding terbalik dengan luas wilayah Pulau Lombok yang sempit.

Sebagai ekosistem pulau kecil, Pulau Lombok memiliki keanekaragaman hayati yang cukup tinggi, namun juga memiliki resiko lingkungan yang tinggi karena keterbatasan daya dukung lahan yang sempit. Laju pertumbuhan penduduk akan mendorong bertambahnya permintaan konsumsi sumberdaya yang dapat berimplikasi negatif terhadap pemanfaatan ruang. Hal ini dapat memicu terjadinya konversi lahan dan alih fungsi lahan pertanian menjadi lahan non pertanian dimana setiap tahunnya lahan pertanian seperti sawah luasannya semakin berkurang seiring dengan meningkatnya jumlah penduduk dan pesatnya perkembangan ekonomi. Hal ini akan dapat mempengaruhi jumlah produksi padi dimasa yang akan datang. Salah satu dampak konversi lahan yang sering mendapat sorotan masyarakat luas adalah terganggunya ketahanan pangan yang merupakan salah satu tujuan pembangunan nasional (Irawan, 2005). Tantangan utama dalam penyediaan sumberdaya saat ini dan dimasa yang akan datang adalah ketersediaan sumber daya lahan yang makin langka (lack of resources), baik luas maupun kualitasnya serta konflik penggunaannya (conflict of interest) (Pasandaran, 2006).

Oleh karena itu arahan pemanfatan ruang dan pendugaan tentang berbagai kebutuhan penting dilakukan sehingga diharapkan dapat mewujudkan pemanfaatan ruang yang berhasil dan berdaya guna untuk mewujudkan pembangunan berkelanjutan. Alat yang dapat digunakan dalam pendugaan kebutuhan dan ketersediaan sumberdaya adalah pendekatan tapak ekologi atau sering disebut Ecological Footprint. Tapak ekologi suatu pendekatan yang dapat digunakan untuk menghitung seberapa besar daya dukung dan daya tampung yang tersedia untuk memenuhi kebutuhan manusia yang terus bertambah. Tapak ekologi diperhitungkan menggunakan global hektar. Pentingnya evaluasi tapak ekologis yang ada di Pulau Lombok dapat menjadi suatu masukan untuk dapat mengetahui bagaimana ketersedian sumberdaya yang ada untuk memenuhi kebutuhan penduduk setempat maupun penduduk daerah lain, sehingga dapat menjadi acuan dalam perencanaan penggunaan ruang sebagai upaya mewujudkan pembangunan yang berkelanjutan dan diharapkan dapat bermanfaat sebagai alat penunjang keputusan bagi pengambil kebijakan dalam mewujudkan kemandirian pangan berkelanjutan.

Penelitian ini bertujuan untuk: 1) Menetapkan status tapak ekologi di Pulau Lombok melalui pendekatan Demand (permintaan) dan Supply (pasokan) lahan berdasarkan Global Footprint Network, Kesesuaian Lahan dan Rencana Tata Ruang Wilayah, 2) Mengevaluasi dan menilai ketiga pendekatan perhitungan tapak ekologi, 3) Merumuskan arahan pemanfaatan ruang berdasarkan hasil perhitungan nilai tapak ekologi.

\section{METODE PENELITIAN}

Penelitian ini dilaksanakan di Pulau Lombok. Pulau Lombok merupakan salah satu Pulau yang berada pada wilayah administrasi provinsi Nusa Tenggara Barat. Secara geografis, Lombok terletak pada koordinat 116 35'1” BT dan 8॰56'5” LS yang terdiri dari 4 
(empat) kabupaten dan 1 (satu) Kota yaitu Kabupaten Lombok Barat, Lombok Tengah, Lombok Timur, Lombok Utara, dan Kota Mataram. Jenis data yang digunakan dalam penelitian ini berupa jenis data sekunder dan data primer. Data skunder: Peta Administrasi, Peta RTRW, data Kesesuaian lahan, Data Statistik, dokumen RTRW provinsi Nusa Tenggara Barat, Profil Pulau Lombok, data tentang luas lahan dan data lainnya. Sedangkan untuk data primer berupa hasil pengamatan tentang kondisi fisik wilayah di lapangan oleh peneliti. Data sekunder diperoleh dari studi literatur dan dokumen dari instansi terkait di lokasi penelitian. Data Skunder diperoleh dari instansi pemerintah, baik dari BAPPEDA, BPS, Dinas PU, Dinas Pertanian dan Peternakan, Dinas Kehutanan dan Perkebunan, Dinas Penataan Ruang, Perikanan dan Kelautan.

\section{Tahap Perhitungan Tapak Ekologi}

Dalam hal ini pendekatan yang digunakan adalah pendekatan tapak ekologi (ecological footprint) guna menghitung tingkat konsumsi terhadap sumberdaya, dan didasarkan pada pemikiran bahwa ketersediaan sumberdaya alam hayati (ruang) yang produktif dibutuhkan untuk kelangsungan hidup manusia. Pendekatan tapak ekologi ini memperhatikan tingkat konsumsi populasi, dimana perbedaan kebutuhan area dengan ketersedian kapasitas ekologi dapat menunjukkan adanya overshoot atau undershoot pemanfaatan sumberdaya. Bagian penting untuk mendapatkan nilai defisit ekologi dari perhitungan tapak ekologi suatu wilayah atau zona khususnya di Pulau Lombok diwakili oleh perhitungan kapasitas biologisnya (pasokan/supply) dan kapasitas tapak ekologi (permintaan/demand) dari setiap kategori lahan penggunaan yang ada di wilayah yang diteliti.

Menurut (BK Bala \& Hossain MA, 2012) Perhitungan tapak ekologi didasarkan pada data ratarata konsumsi, dan ini diubah menjadi penggunaan lahan produktif. Tanah bioproduktif dibagi menjadi enam kategori sesuai dengan klasifikasi World Conservation Union: (1) lahan pertanian, (2) lahan penggembalaan, (3) hutan, (4) fishing ground, (5) build-up land dan (6) lahan energi. Tapak ekologi total adalah jumlah dari tapak ekologi dari semua kategori lahan yang memberikan kebutuhan eksklusif pada biosfer.

Permintaan dan Pasokan berdasarkan GFN (Global footprint Network)

Menurut (Ewing et al., 2010) dalam Ecological Footprint Atlas 2010 mengungkapkan bahwa nilai Tapak Ekologi dapat dihitung dengan persamaan berikut:

$E F=\frac{P}{Y N} \times E q F$

Dimana :

EF : Permintaan/Demand/Tapak ekologi (gha)

$P \quad$ : Jumlah produksi (ton/ha)

$Y_{N} \quad$ : Produktifitas rata-rata untuk P di Pulau Lombok (ton/ha)

YF : Faktor Panen/ Yield Factor

EqF : Faktor Penyama/ Equivalence Factor (gha)

Tapak ekologi menggambarkan kebutuhan barang dan jasa yang diperlukan oleh manusia dari alam yang dicerminkan dalam konsumsi bersih (net consumption) dari produkproduk yang dikategorikan seperti produk pertanian, produk peternakan, produk kehutanan, produk perikanan, keperluan ruang dan lahan, serta konsumsi energi. Konsumsi bersih merupakan konsumsi aktual yang dipengaruhi oleh kegiatan perdagangan (ekspor-impor). Perhitungan konsumsi aktual akan menambahkan barang yang diimpor dan mengurangi barang yang diekspor yang dinyatakan dengan persamaan berikut:

Konsumsi Bersih/Total (ton) = Produksi Lokal (ton) + Impor (ton) - Ekspor (ton) 
Biokapasitas adalah kapasitas ekosistem untuk menghasilkan material-material biologi yang berguna dan kapasitas untuk menyerap buangan material yang dihasilkan oleh kegiatan manusia dengan menggunakan cara pengelolaan dan teknologi yang dikuasai saat ini. Seperti halnya tapak ekologi, biokapasitas terdiri dari 6 (enam) kategori lahan, yaitu lahan pertanian, lahan peternakan, lahan kehutanan, lahan perikanan, lahan terbangun dan lahan penyerap karbon.

Menurut ketentuan (Ewing et al., 2010) lahan penyerap karbon dianggap tidak memiliki nilai biokapasitas (ditunjukkan dalam seluruh tabel nilai biokapasitas lahan penyerap karbon adalah 0), berdasarkan asumsi bahwa seluruh penyerapan karbon dilakukan oleh lahan kehutanan sehingga nilai biokapasitas lahan penyerap karbon adalah 0 (nol) atau merupakan objek dari biokapasitas lahan kehutanan. Pada metoda perhitungan ini, nilai tapak ekologi dan biokapasitas lahan terbangun adalah sama. Permintaan akan lahan terbangun dan infrastruktur (EF lahan terbangun) terhadap persediaan lahan (BK lahan terbangun) akan berbanding lurus, dimana setiap pembukaan lahan baru akan selalu diiringi dengan tumbuhnya lahan terbangun. Biokapasitas (BK/BC) untuk semua kategori lahan dihitung dengan menggunakan persamaan:

$B K=A \times Y F \times E q F$

Dimana :

BK : Pasokan/Supply/Biokapasitas (gha)

$A \quad$ : Luas setiap kategori lahan (ha)

$\boldsymbol{Y F} \quad$ : Faktor Panen/Yield Factor

EqF : Faktor Penyama/ Equivalenc Factor (gha)

Dalam perhitungan, sumber data yang digunakan adalah data statistik NTB dalam angka 2015 dari Badan Pusat Statistik propinsi Nusa Tenggara Barat dan data pendukung lainnya yang berasal dari instansi terkait. Untuk Faktor Penyama (Equivalenc Factor) dan Faktor Panen (Yield Factor) menggunakan ketetapan berdasarkan GFN (Wackernagel et al., 2005). Adapun nilai Faktor Penyama/Equivalenc Factor tiap kategori lahan berdasarkan GFN dapat dilihat pada Tabel 1.

Tabel 1. Nilai Faktor Penyama dan Faktor Panen berdasarkan GFN

\begin{tabular}{lcc}
\hline Lahan Bioproduktif & Faktor Penyama (gha) & Faktor Panen \\
\hline Lahan Pertanian & 2,19 & - \\
- Pertanian Primer & 2,19 & 0,98 \\
- Pertanian Marginal & 1,80 & 2,57 \\
Lahan Pengembalaan & 0,48 & 1,81 \\
Lahan Kehutanan & 1,37 & 0,82 \\
Lahan Perikanan & 0,36 & 3,39 \\
Lahan Terbangun & 2,19 & 0,98 \\
Lahan Penyerap Karbon & 1,37 & 2,96 \\
\hline
\end{tabular}

Sumber: Wackernagel et al., 2005

\section{Asumsi Perhitungan:}

Untuk mendapatkan nilai tapak ekologi di Pulau Lombok, digunakan data jumlah produksi setiap komoditas yang ada pada lahan pertanian, terdiri dari jenis tanaman pangan dan holtikultura serta tanaman perkebunan. Komoditas yang dihitung merupakan jenis komoditas unggulan yang ada di Pulau Lombok saat ini. Jumlah produksi yang ada dibagi dengan produktivitas nasional propinsi NTB pada setiap komoditas kemudian dikalikan dengan faktor penyama untuk menghasilkan nilai dalam satuan hektar global. Tapak ekologi lahan pengembalaan di Pulau Lombok dihitung dengan membandingkan seberapa besar jumlah konsumsi daging yang dibutuhkan (sapi, kerbau, kambing) dengan seberapa besar jumlah daging yang mampu diproduksi oleh ternak lahan pengembalaan jika dibandingkan dengan luas lahan untuk pakan ternak yang disediakan di tahun tersebut.

Nilai Tapak ekologi lahan hutan dihitung berdasarkan jumlah produksi kayu baik kayu bulat maupun kayu bakar yang dikonsumsi oleh masyarakat Pulau Lombok pada tahun tersebut. Nilai tapak ekologi lahan perikanan di Pulau Lombok dihitung berdasarkan pada 
produksi primer yang diperlukan untuk mendukung ikan yang ditangkap. Produksi lahan perikanan ini dibagi menjadi perikana darat (tangkap, budidaya, kolam) dan perikanan laut yang ada di Pulau Lombok. Tapak ekologi lahan terbangun di Pulau Lombok dihitung berdasarkan luas lahan yang ditutupi oleh infrastruktur manusia baik transportasi, perumahan maupun industri. Diasumsikan bahwa lahan terbangun menempati apa yang sebelumnya terdapat pada lahan pertanian, karena pemukiman manusia umumnya terletak di daerah yang sangat subur. Untuk mendapatkan nilai tapak ekologi lahan terbangun dibutuhkan data tentang jumlah rumah tangga, jumlah populasi dan standar kebutuhan lahan per orang/penduduk.

Tapak karbon pada perhitungan tapak ekologi di Pulau Lombok dihitung berdasarkan daya serap karbon dioksida dikalikan dengan luas lahan hutan sebagai salah satu tutupan lahan yang berfungsi sebagai penyerap karbon, terutama karbon dari hasil pembakaran bahan bakar fosil, atau produk limbah. Disisi permintaan, Tapak karbon dihitung sebagai jumlah hutan yang dibutuhkan untuk menyerap emisi karbon dioksida pada atmosfer dari pembakaran bahan bakar fosil, perubahan penggunaan lahan (deforestasi, misalnya), dan emisi dari transportasi.

\section{Permintaan dan Pasokan berdasarkan Kesesuaian Lahan}

Menurut rumus yang digunakan untuk menghitung nilai Demand-supply berdasarkan penentuan GFN yang disesuaikan dengan kelas kesesuaian lahannya. Rumus yang digunakan untuk menghitung nilai Demand-supply berdasarkan kesesuaian lahan adalah sebagai berikut.

Untuk perhitungan Permintaan (demand) digunakan rumus:

$E F=A s \times E q F$

Dimana:

EF : Permintaan/Demand/Tapak ekologi (gha)

As : Luas lahan yang sesuai (ha)

EqF :Paktor penyama/Equivalence Factor (ha)

Untuk perhitungan Pasokan/supply.

$B K=L e \times Y F \times E q F$

Dimana:

BK : Pasokan/supply/Biokapasistas berdasarkan Kesesuaian (gha)

Le : Luas lahan eksisting (ha)

EqF : Paktor penyama/ Equivalence Factor (ha)

YF : Faktor Panen/ Yield Factor (gha)

\section{Asumsi Perhitungan:}

Dalam perhitungan menggunakan pendekatan kesesuaian lahan digunakan data kesesuaian lahan untuk berbagai peruntukan yang ada di Pulau Lombok. Kategori lahan kesesuaian yang digunakan untuk menghitung demand meliputi kelas sesuai 1, sesuai 2 dan sesuai 3. Data kesesuaian lahan yang digunakan dalam perhitungan permintaan maupun pasokan tapak ekologi Pulau Lombok disadur dari data kesesuaian lahan hasil penelitian 
kesesuaian lahan untuk berbagai kategori penggunaan lahan yang telah dilakukan oleh (Widiatmaka et al., 2015).

Perhitungan tapak ekologi berdasarkan kesesuaian lahan dihitung dengan mempertimbangkan luas kesesuaian lahan yang ada pada enam kategori penggunaan lahan yang dinilai. Perhitungan nilai biokapasitas pada pendekatan kesesuaian lahan menggunakan data eksisiting yang ada saat ini. Data kesesuaian lahan yang ada meliputi data kesesuaian untuk lahan pertanian tanaman pangan dan kesesuaian untuk tanaman perkebunan serta lahan kesesuaian untuk lahan pengembalaan.

Terdapat beberapa data kesesuaian yang tidak tersedia sehingga karena keterbatasan data yang ada beberapa kategori kesesuaian penggunaan lahan seperti untuk hutan, perikanan, lahan terbangun dan lahan penyerapan karbon dihitung menggunakan data luas lahan eksisting atau yang tersedia saat ini dengan asumsi bahwa luas lahan yang dimanfaatkan saat ini oleh penduduk adalah lahan yang dianggap sesuai dan luasnya kemudian dikalikan dengan faktor panen dan faktor penyama pada perhitungan permintaan maupun pasokan yang ada.

\section{Permintaan dan Pasokan berdasarkan Rencana Tata Ruang Wilayah (RTRW)}

Bagian penting untuk mendapatkan nilai defisit ekologi dari perhitungan tapak ekologi suatu wilayah khususnya di Pulau Lombok diwakili oleh perhitungan kapasitas biologisnya (pasokan/supply) dan kapasitas tapak ekologi (permintaan/demand) dari setiap kategori lahan penggunaan yang ada di wilayah yang diteliti. Menurut (Sekretariat Negara, 2009) dalam Permen LH Nomor: 17 tahun 2009, untuk perhitungan demand yang sesuai dengan RTRW digunakan analisis ketersediaan ruang dan analisis kebutuhan ruang diadopsi dari rumus daya dukung dan daya tampung sesuai dengan dengan modifikasi rumus tapak ekologi sebagai berikut:

$E F=D L \times E q F$

Dimana:

DL : Kebutuhan Lahan (ha)

EqF :Paktor penyama/Equivalence Factor (ha)

Kebutuhan lahan setiap penduduk dihitung menggunakan rumus:

$D L=N \times K H L_{L}$

Dimana:

$N \quad$ : Jumlah penduduk (orang)

$K H L_{L}$ : Luas lahan yang dibutuhkan untuk kebutuhan hidup layak per penduduk, dengan ketentuan.

Untuk perhitungan Pasokan/supply.

$B K=L T_{R T R W} \times Y F \times E q F$

Dimana:

BK : Pasokan/Supply/Biokapasitas (gha)

$L T_{R T R W}:$ Luas lahan yang tersedia di dalam RTRW

EqF : Paktor penyama/ Equivalence Factor (ha)

YF : Faktor Panen/ Yield Factor (gha) 


\section{Asumsi Perhitungan:}

Dalam mencari nilai tapak ekologi (EF) kebutuhan lahan setara beras dihitung dengan cara mengalikan jumlah penduduk yang ada di Pulau Lombok dengan standar kebutuhan lahan sesuai standar Indonesia dalam kategori penggunaan ruang yang diadopsi dari data Laporan Final Kajian daya Dukung Lingkungan 2007 (Rusli, Widiono, \& Indriana, 2010) Standar kebutuhan untuk hidup layak setiap penduduk pertahunnya adalah sebesar 0,78\% terbagi dalam bebrapa kategori kebutuhan lahan. Standar kebutuhan hidup layak setiap penduduk dapat dilihat pada Tabel 2.

Tabel 2. Kebutuhan Lahan perorang pertahun berdasarkan kriteria di Indonesia

\begin{tabular}{lcc}
\hline Kebutuhan Lahan & Jumlah (ha/orang) & Persentase \\
\hline Lahan Pertanian & 0,13 & 1,66 \\
Kebun & 0,026 & 3,33 \\
Lahan Peternakan & 0,072 & 9,21 \\
Lahan Terdegradasi & 0,26 & 33,30 \\
Lahan Energi & 0,201 & 25,70 \\
Hutan & 0,21 & 26,9 \\
\hline Total Kebutuhan Lahan & 0,78 & 100 \\
\hline
\end{tabular}

Sumber: Rusli et al., 2010

Menurut (Sekretariat Negara, 2002) dalam Kepmenkimpraswil No.403/KPTS/M/2002 Untuk standar kebutuhan kategori lahan terbangun digunakan ketentuan yang tertera bahwa luas lahan yang dibutuhkan untuk hidup layak per penduduk efektifnya adalah $90 \mathrm{~m}$ (0,09 ha/orang). Setelah diketahui seberapa besar luas kebutuhan lahan sesuai dengan kategori penggunaan lahan yang ada kemudian luas kebutuhan lahan dikalikan dengan faktor panen dan faktor penyama guna mendapatkan nilai tapak ekologi dalam satuan global hektar.

Sedangkan untuk mengetahui seberapa besar jumlah pasokan yang tersedia, digunakan data luas lahan berbagai kategori penggunaan yang tersedia atau sudah dialokasikan di dalam RTRW provinsi NTB khususnya di Pulau Lombok. Luas lahan yang tersedia dikalikan dengan faktor panen dan faktor penyama sesuai dengan rumus persamaan guna mendapatkan nilai pasokan dalam besaran global hektar (gha).

\section{Defisit Ekologi/Ecological Footprint Deficit (ED)}

Menurut (Direktorat Jendral Penataan Ruang, 2010) dasar pemikiran analisis pendekatan ini berasal dari kemampuan lingkungan untuk mendukung kehidupan manusia. Dalam penelitian ini untuk mengetahui nilai defisit ekologi dan status tapak ekologi yang ada serta untuk mendapatkan hasil perhitungan nilai biokapasitas yang bernilai surplus dan defisit maka digunakan rumus perhitungan sebagai berikut.

$E D=B C_{\text {Total }}-E F_{\text {Total }}$

Dimana:

ED : Defisit ekologi/Neraca Ekologi

$\boldsymbol{B C}_{\text {Total }} \quad$ : Pasokan/supply total

EF Total : Permintaan/demand total 
Luasan permintaan (area demanded) bisa lebih besar dari luasan pasokan (area supplied), jika permintaan suatu ekosistem melebihi kemampuan ekosistem untuk menyediakannya maka dapat bernilai defisit dan jika masih mampu maka dapat dikategorikan bernilai surplus sumberdaya. Hasil yang diperoleh berupa besaran gha. Adapun masing-masing nilai EF dan BC dinormalisasikan dengan equivalence factor. Status ekologi dinyatakan sebagai perbedaan antara biokapasitas dan tapak ekologi. Status negatif ekologi (BC<EF) menunjukkan bahwa tingkat konsumsi sumber daya alam lebih besar dari tingkat produksi (regenerasi) oleh ekosistem lokal. Dengan demikian, defisit ekologi (BC $<E F)$ atau surplus $(\mathrm{BC}>\mathrm{EF})$ memberikan estimasi dari keberlanjutan lingkungan atau tidak berkelanjutan.

\section{Tahap Pemilihan Pendekatan dan Perumusan Arahan Pemanfaatan}

Berdasarkan tiga pendekatan perhitungan tapak ekologi yang digunakan, dipilih salah satu pendekatan yang dianggap baik untuk menghitung nilai dan menggambarkan kondisi Tapak Ekologi guna mempertahankan keberlanjutan ekosistem yang ada di Pulau Lombok. Pemilihan pendekatan perhitungan tapak ekologi di Pulau Lombok mempertimbangkan hasil perhitungan tapak ekologi, legalitas hukum, keuntungan dan kelemahan setiap pendekatan.

Hasil perhitungan nilai tapak ekologis yang sudah dievaluasi serta dianalisis dijadikan sebagai acuan dalam menyusun kebijakan arahan pemanfaatan ruang yang ada di Pulau Lombok. Secara lebih spesifik, kebijakan yang dimaksud diharapkan dapat difokuskan pada komponen yang menjadi dasar perhitungan biokapasitas dan tapak ekologi (pertanian, perikanan, kehutanan, peternakan, lahan penyerap karbon dan lahan terbangun).

\section{HASIL DAN PEMBAHASAN}

\section{Permintaan-Pasokan berdasarkan Global Footprint Network (GFN) Tahun 2015}

Nilai permintaan (demand) berdasarkan Global Footprint Network (GFN) menunjukkan bahwa total jumlah permintaan sumberdaya diberbagai jenis penggunaan ruang adalah sebesar 0,42649 gha/jiwa. Permintaan sumberdaya paling tinggi di wilayah Pulau lombok berada pada kategori penggunaan lahan pertanian sebesar 0,27629 gha/jiwa. Sedangkan perhitungan nilai pasokan (supply) diketahui bahwa ketersediaan sumberdaya yang ada di Pulau Lombok sebesar 0,44627 gha/jiwa. Pasokan sumberdaya yang paling tinggi tersedia pada kategori penggunaan lahan pertanian sebesar 0,27433 gha/jiwa.

Tabel 3. Keseimbangan Ekologi Kategori Lahan Pulau Lombok berdasarkan Global Footprint Network (GFN) Tahun 2015

\begin{tabular}{llcrrl}
\hline No & \multicolumn{1}{c}{ Kebutuhan Lahan } & $\begin{array}{c}\text { Permintaan } \\
\text { (Demand) }\end{array}$ & $\begin{array}{c}\text { Pasokan } \\
\text { (Supply) }\end{array}$ & \multicolumn{1}{c}{$\begin{array}{c}\text { Neraca } \\
\text { Ekologi }\end{array}$} & \multicolumn{1}{c}{$\begin{array}{c}\text { Tapak } \\
\text { Ekologi }\end{array}$} \\
\hline 1 & Lahan Pertanian & 0,27629 & 0,27433 & $-0,00196$ & Defisit \\
2 & Lahan Peternakan & 0,03126 & 0,02075 & $-0,01050$ & Defisit \\
3 & Lahan Perikanan & 0,00301 & 0,00305 & 0,00004 & Surplus \\
4 & Lahan Kehutanan & 0,00764 & 0,00274 & $-0,00490$ & Defisit \\
5 & Lahan Terbangun & 0,07860 & 0,06401 & $-0,01459$ & Defisit \\
6 & Lahan Penyerap Karbon & 0,02969 & 0,08139 & 0,05170 & Surplus \\
& Total & 0,42649 & 0,44627 & 0,01978 & Surplus \\
\hline
\end{tabular}

Perhitungan permintaan dan pasokan menggunakan GFN mengasilkan nilai keseimbangan ekologi sebesar 0,01978 gha/jiwa (Tabel 3). Hal ini menunjukkan bahwa secara keseluruhan Pulau Lombok berada pada kategori Wilayah Surplus sumberdaya. Kondisi lahan perikanan dan penyerap karbon relatif masih aman meskipun pada lahan penyerap karbon dapat dilihat permintaan cenderung tinggi namun jumlah pasokan masih mampu untuk memenuhi permintaan sumberdaya. 
Permintaan-Pasokan berdasarkan Kesesuaian Lahan Tahun 2015

Perhitungan permintaan (demand) menunjukkan bahwa jumlah permintaan akan sumberdaya di Pulau lombok sebesar 0,40678 gha/jiwa dengan permintaan suberdaya yang paling tinggi berada pada kategori lahan petanian dan penyerapan karbon. Nilai pasokan (supply) sumberdaya di Pulau Lombok sebesar 0,62144 gha/jiwa. Lahan pertanian dan lahan penyerapan karbon memiliki nilai pasokan sumberdaya yang paling tinggi. Meskipun demikian jika dibandingkan dengan jumlah permintaannya yang relatif besar nilai pasokan masih mampu memenuhi segala permintaan yang ada karena kondisi tapak ekologi pada ruang pertanian tergolong wilayah surplus.

Kondisi tapak ekologi di Pulau Lombok secara keseluruhan berdasarkan pendekatan kesesuaian lahan hampir sama dengan pendekatan GFN yaitu berada dalam kondisi Wilayah Surplus sumberdaya dengan nilai defisit ekologi sebesar 0,21466 gha (Tabel 4). Kondisi tapak ekologi seperti ini perlu dipertahankan seterusnya agar tidak mengalami kondisi defisit dimasa yang akan datang. Dalam perhitungan menggunakan pendekatan kesesuaian lahan permintaan terbesar berada pada jenis penggunaan lahan pertanian sebesar 0,22177 gha/jiwa, menandakan bahwa kebutuhan lahan pertanian cukup tinggi untuk berbagai kebutuhan baik untuk pembangunan maupun pengolahan lahan pertanian itu sendiri.

Tabel 4. Keseimbangan Ekologi Kategori Lahan Pulau Lombok berdasarkan Kesesuaian Lahan di Pulau Lombok Tahun 2015

\begin{tabular}{llcrrl}
\hline No & \multicolumn{1}{c}{ Kebutuhan Lahan } & $\begin{array}{c}\text { Permintaan } \\
\text { (Demand) }\end{array}$ & $\begin{array}{c}\text { Pasokan } \\
\text { (Supply) }\end{array}$ & $\begin{array}{c}\text { Neraca } \\
\text { Ekologi }\end{array}$ & \multicolumn{1}{c}{$\begin{array}{c}\text { Tapak } \\
\text { Ekologi }\end{array}$} \\
\hline 1 & Lahan Pertanian & 0,22177 & 0,27542 & 0,05365 & Surplus \\
2 & Lahan Peternakan & 0,04230 & 0,06799 & 0,02569 & Surplus \\
3 & Lahan Perikanan & 0,00301 & 0,01020 & 0,00719 & Surplus \\
4 & Lahan Kehutanan & 0,00764 & 0,00627 & $-0,00138$ & Defisit \\
5 & Lahan Terbangun & 0,06531 & 0,06401 & $-0,00131$ & Defisit \\
6 & Lahan Penyerap Karbon & 0,06674 & 0,19755 & 0,13081 & Surplus \\
\hline & Total & $\mathbf{0 , 4 0 6 7 8}$ & $\mathbf{0 , 6 2 1 4 4}$ & $\mathbf{0 , 2 1 4 6 6}$ & Surplus \\
\hline
\end{tabular}

Permintaan-Pasokan berdasarkan Rencana Tata Ruang Wilayah (RTRW)

Perhitungan demand berdasarkan RTRW menunjukkan jumlah permintaan sumberdaya di Pulau Lombok sebesar 1,62639 gha/jiwa dengan nilai permintaan paling besar berada pada kategori penggunaan lahan Pertanian dan lahan penyerapan karbon, sedangkan jumlah pasokan (supply) sumberdaya menunjukkan nilai sebesar 0,63173 gha/jiwa (Tabel 5). Nilai pasokan terbesar terdapat pada kategori lahan penyerap karbon dan lahan pertanian.

Pasokan sumberdaya pada penggunaan lahan peternakan relatif masih aman karena berada pada kondisi surplus, namun yang perlu diwaspadai adalah kondisi tapak ekologi pada ketegori penggunaan lahan selain peternakan dimana semuanya bernilai defisit jika dibandingkan dengan penggunaan lahan peternakan. Jika nilai pasokan tidak mampu mengimbangi tingginya permintaan yang ada maka Pulau Lombok akan mengalami defisit sumberdaya untuk memenuhi kebutuhan penduduknya. Perhitungan berdasarkan RTRW menempatkan posisi tapak ekologi Pulau Lombok berada pada kategori Wilayah Defisit sumberdaya. 
Tabel 5. Keseimbangan Ekologi Kategori Lahan Pulau Lombok Berdasarkan Rencana Tata Ruang Wilayah (RTRW) Tahun 2015

\begin{tabular}{llcccl}
\hline No & \multicolumn{1}{c}{ Kebutuhan Lahan } & $\begin{array}{c}\text { Permintaan } \\
\text { (Demand) }\end{array}$ & $\begin{array}{c}\text { Pasokan } \\
\text { (Supply) }\end{array}$ & $\begin{array}{c}\text { Neraca } \\
\text { Ekologi }\end{array}$ & $\begin{array}{c}\text { Tapak } \\
\text { Ekologi }\end{array}$ \\
\hline 1 & Lahan Pertanian & 0,44525 & 0,19776 & $-0,24749$ & Defisit \\
2 & Lahan Peternakan & 0,04519 & 0,09989 & 0,05470 & Surplus \\
3 & Lahan Perikanan & 0,09088 & 0,01020 & $-0,08068$ & Defisit \\
4 & Lahan Kehutanan & 0,36106 & 0,05277 & $-0,30829$ & Defisit \\
5 & Lahan Terbangun & 0,30825 & 0,06401 & $-0,24424$ & Defisit \\
6 & Lahan Penyerap Karbon & 0,37576 & 0,20710 & $-0,16866$ & Defisit \\
\hline & Total & $\mathbf{0 , 4 0 6 7 8}$ & $\mathbf{0 , 6 2 1 4 4}$ & $\mathbf{0 , 2 1 4 6 6}$ & DEFISIT \\
\hline
\end{tabular}

Penilaian Tiga Pendekatan Perhitungan Tapak Ekologi

Setiap pendekatan yang digunakan dalam perhitungan tapak ekologi di Pulau Lombok memiliki kelebihan dan kekurangan disetiap aplikasinya. Sesuai dengan hasil perhitungan menggunakan tiga pendekatan tersebut diperoleh hasil dimana, pendekatan GFN menempatkan Pulau Lombok berada pada kondisi wilayah sedikit defisit. Sedangkan berdasarkan kesesuaian lahannya Pulau Lombok berada pada kondisi wilayah surplus, dan untuk pendekatan RTRW menempatkan Pulau Lombok berada pada kondisi wilayah defisit.

Tabel 6. Perbandingan Nilai Tapak Ekologi Pulau Lombok Tahun 2015 berdasarkan Ketiga Pendekatan

\begin{tabular}{|c|c|c|c|c|c|c|c|}
\hline \multirow[t]{2}{*}{ No } & \multirow[t]{2}{*}{ Penggunaan Lahan } & \multicolumn{3}{|c|}{2015} & \multicolumn{3}{|c|}{2035} \\
\hline & & EF & $\mathrm{BC}$ & NE & $\mathrm{EF}$ & $\mathrm{BC}$ & $\mathrm{NE}$ \\
\hline 1 & Lahan Pertanian & 0,44525 & 0,19776 & $-0,24749$ & 0,32630 & 0,14493 & $-0,18137$ \\
\hline 2 & Lahan Peternakan & 0,04519 & 0,09989 & 0,05470 & 0,03312 & 0,07321 & 0,04009 \\
\hline 3 & Lahan Perikanan & 0,09088 & 0,01020 & $-0,08068$ & 0,06660 & 0,00748 & $-0,05912$ \\
\hline 4 & Lahan Kehutanan & 0,36106 & 0,05277 & $-0,30829$ & 0,26460 & 0,03867 & $-0,22593$ \\
\hline 5 & Lahan Terbangun & 0,30825 & 0,06401 & $-0,24424$ & 0,22590 & 0,04691 & $-0,17899$ \\
\hline 6 & Penyerap & 0,37576 & 0,20710 & $-0,16866$ & 0,27537 & 0,15177 & -012360 \\
\hline & Total & 1,62639 & 0,63173 & $-0,99467$ & 1,19189 & 0,46296 & $-0,72893$ \\
\hline & Status & & ilayah Desif & & Wilayah D & & \\
\hline
\end{tabular}

Keterangan: EF: Permintaan, BC: Pasokan, NE: Neraca Ekologi.

Dalam kajian ini dari ketiga pendekatan yang digunakan, dinilai cukup baik berdasarkan pertimbangan kelemahan dan kelebihan yang dimiliki, maka pendekatan yang lebih nyata dalam menggambarkan kondisi tapak ekologi Pulau Lombok adalah pendekatan RTRW.

Pendekatan ini memberikan gambaran kondisi tapak ekologi Pulau Lombok secara nyata dilihat dari ketersediaan ruang yang dialokasikan oleh pemerintah melalui sebuah rencana tata ruang wilayah. Meskipun nilai tapak ekologi yang diperoleh dari perhitungan bernilai Defisit dan secara tertulis masih merupakan sebuah rancangan, namun mengacu pada peraturan pemerintah dan memiliki legal formal yang kuat dan diatur di dalam undangundang sehingga dapat mengontrol berbagai aktivitas penggunaan ruang. Pemerintah juga dapat menekan tingginya permintaan lahan untuk berbagai penggunaaan terutama pada penggunaan yang tidak sesuai dengan alokasi dan peruntukannya. Pendekatan RTRW dapat menjadi salah satu bentuk intervensi untuk mengatur interaksi manusia bahkan makhluk hidup lainnya dengan lingkungan agar dapat berjalan serasi, selaras, seimbang untuk kesejahteraan dan kelestarian serta keberlanjutan pembangunan, dan umumnya berbagai tujuan yang terdapat dalam pendekatan RTRW berusaha untuk mengintegrasikan berbagai penggunaan ruang secara selaras dan seimbang. 
Keseimbangan Ekologis Pulau Lombok Tahun 2035

Jumlah penduduk Pulau Lombok pada tahun 2035 diperkirakan bertambah sebesar 4.575.319 jiwa dengan laju pertumbuhan penduduk 1,56 persen setiap tahunnya artinya selama dua puluh tahun kedepan penduduk Pulau Lombok akan bertambah hingga mencapai 1.222.331 jiwa. Dengan pertambahan jumlah penduduk yang tinggi di tahun 2035 ada suatu kemungkinan dimana nilai defisit ekologi Pulau Lombok akan bertambah karena pengaruh jumlah permintaan dan pasokan sumberdaya untuk pemenuhan kebutuhan penduduknya. Hal ini tentu saja dapat mempengaruhi rencana pemerintah daerah dalam mewujudkan program pembangunan berkelanjutan yang ada di Pulau Lombok.

Pada perhitungan nilai tapak ekologi Pulau Lombok tahun 2015 jumlah permintaan berdasarkan pendekatan RTRW sebesar 1,62639 gha/jiwa dengan jumlah pasokan sebesar 0,63173 gha/jiwa menempatkan Pulau Lombok berada pada wilayah defisit sumberdaya. Pada tahun 2035 dengan laju konversi sebesar 4,5\% diperkirakan jumlah permintaan sumberdaya mengalami penurunan namun dengan jumlah pasokan sumberdaya yang terus berkurang menyebabkan kondisi tapak ekologi Pulau Lombok masih berada pada wilayah defisit sumberdaya dengan nilai defisit ekologi sebesar -0,72893 gha/jiwa (Tabel 6).

Terjadi perubahan pada lahan peternakan yang semula merupakan wilayah cadangan berubah menjadi wilayah seimbang. Artinya jumlah pasokan/supply sumberdaya berkurang yang menandakan terjadi penurunan kemampuan dalam memenuhi kebutuhan tapak ekologi masyarakat yang ada di wilayah Pulau Lombok, namun wilayahnya mampu menekan jumlah permintaan sumberdaya hingga 1,19189 gha/jiwa. Jika melihat besarnya jumlah permintaan, penggunaan pendekatan RTRW mampu mengurangi jumlah defisit sumberdaya dari 0,99467 gha turun menjadi $-0,72893$ gha. Meskipun demikian jika jumlah pasokan sumberdaya tidak dialokasikan dengan baik di dalam RTRW, maka tetap tidak akan dapat mengimbangi besarnya jumlah permintaan meskipun telah terjadi penurunan.

Pada tahun 2035 nilai permintaan terbesar berada pada kategori lahan pertanian, perikanan, lahan terbangun dan lahan penyerap karbon dimana nilai defisit ekologinya berada pada kondisi defisit. Hal ini memerlukan perhatian khusus mengingat adanya peristiwa pemanasan global yang dipengaruhi oleh segara aktivitas manusia baik kegiatan ekonomi, industri, tambang, perubahan penggunaan lahan serta kegiatan pembangunan lainnya dapat berpengaruh besar terutama pada luas lahan pertanian dan juga lahan penyerapan karbon. Peristiwa pemanasan global yang dipengaruhi oleh segara aktivitas manusia baik kegiatan ekonomi, industri, tambang, perubahan penggunaan lahan serta kegiatan pembangunan lainnya yang dapat mempengaruhi peningkatan jumlah permintaan.

\section{Arahan Pemanfaatan Ruang Pulau Lombok}

Setelah dilakukan penilaian tapak ekologi menggunakan tiga pendekatan sebelumya dan dipilih salah satu pendekatan yang lebih nyata untuk menggambarkan kondisi tapak ekologi Pulau Lombok saat ini yaitu pendekatan RTRW. Setelah di evaluasi keseimbangan tapak ekologi dengan menggunakan metode trial and error maka dapat disimpulkan bahwa tapak ekologi di Pulau Lombok dapat di kembalikan pada status wilayah surplus apabila laju pertumbuhan penduduknya mampu ditekan dari $1,56 \%$ turun hingga $1 \%$. Selain itu standar kebutuhan hidup layah setiap penduduk seuai kriteria Negara Indonesia dimana setiap orang memiliki standar kebutuhan hidup layak sebesar 0,78\% per tahun diturunkan hingga 0,60\% sampai 0,50 \% sehingga mampu mengembalikan nilai defisit ekologi dalam kondisi surplus sebesar 0,06398 gha/jiwa (Tabel 7).

Nilai defisit ekologi pada setiap penggunaan lahan mampu dikembalikan pada posisi wilayah surplus. Setiap penggunaan lahan yang ada mengalami penambahan dan pengurangan luas lahan sehingga didapatkan nilai keseimbangan ekologi pada wilayah surplus sumberdaya. Dengan menggunakan pendekatan RTRW diperkirakan jika 
permintaan sumberdaya masyarakat Pulau Lombok memperhatikan kesesuaian lahannya penggunaannya, maka Pulau Lombok akan mampu menekan jumlah permintaan sumberdaya diberbagai penggunaan hingga 0, 09663 gha. Oleh karena itu sangat penting disusun suatu arahan pemanfaatan dengan mendasarkan pada tingkat kesesuaian lahan dalam rangka penghematan sumberdaya. Berikut ini adalah arahan pemanfaatan ruang Pulau Lombok yang dibagi ke dalam enam ruang pemanfatanan yang mengau perhitungan kebutuhan sumberdaya berdasarkan rencana tata ruang wilayah dapat dilihat pada Tabel 8.

Tabel 7. Arahan Keseimbangan Ekologi Pulau Lombok Tahun 2035

\begin{tabular}{llcccc}
\hline No & Penggunaan Lahan & $\begin{array}{c}\text { Permintaan } \\
\text { (Demand) }\end{array}$ & $\begin{array}{c}\text { Pasokan } \\
\text { (Supply) }\end{array}$ & $\begin{array}{c}\text { Neraca } \\
\text { Ekologi }\end{array}$ & $\begin{array}{c}\text { Tapak } \\
\text { Ekologi }\end{array}$ \\
\hline 1 & Lahan Pertanian & 0,21210 & 0,23500 & 0,02291 & Surplus \\
2 & Lahan Peternakan & 0,02153 & 0,04503 & 0,02350 & Surplus \\
3 & Lahan Perikanan & 0,04329 & 0,05479 & 0,01150 & Surplus \\
4 & Lahan Kehutanan & 0,10584 & 0,10598 & 0,00014 & Surplus \\
5 & Lahan Terbangun & 0,14684 & 0,14813 & 0,00130 & Surplus \\
6 & Lahan Penyerap & 0,17899 & 0,18363 & 0,00464 & Surplus \\
& Karbon & & & & \\
\hline & Total & $\mathbf{0 , 7 0 8 5 8}$ & $\mathbf{0 , 7 7 2 5 6}$ & $\mathbf{0 , 0 6 3 9 8}$ & SURPLUS \\
\hline
\end{tabular}

Tabel 8. Arahan Pemanfaatan Ruang Pulau Lombok

\begin{tabular}{|c|c|c|}
\hline $\begin{array}{c}\text { Kategori } \\
\text { Lahan }\end{array}$ & Kondisi saat ini & Arahan Pemanfaatan \\
\hline Pertanian & $\begin{array}{l}\text { - Merupakan tumpuan utama sistem produksi } \\
\text { dalam memenuhi konsumsi sumberdaya } \\
\text { masyarakat di Pulau Lombok. } \\
\text { - Lahan pertanian mulai banyak terkonversi } \\
\text { menjadi lahan terbangun dan industri (batu bata } \\
\text { di daerah pringgasela utara, industri genteng di } \\
\text { Montong Gading. } \\
\text { - Di Lombok Timur lahan pertanian juga banyak } \\
\text { yang beralih fungsi menjadi lahan pertambangan } \\
\text { batu apung dan tambang pasir (wilayah Ijobalit }\end{array}$ & $\begin{array}{l}\text { - Lahan pertanian seluas } 269.568 \text { ha perlu } \\
\text { ditambahkan seluas } 121.305 \text { ha. } \\
\text { - Mempertahankan komoditas padi sawah, } \\
\text { tanaman pangan dalam penggunaannya } \\
\text { lahannya. } \\
\text { - Mengendalikan permukiman dan kegiatan } \\
\text { budidaya lainnya pada lahan pertanian serta } \\
\text { penegakan hukum yang tegas oleh para } \\
\text { pemangku kebijakan dalam membatasi } \\
\text { konversi lahan pertanian. }\end{array}$ \\
\hline Petern & $\begin{array}{l}\text { - Banyak didominasi oleh peternakan sapi, } \\
\text { kambing, domba dan kerbau. } \\
\text { - Sistem pengembalaan banyak menggunakan } \\
\text { sistem lepas, namun ada juga yang menggunakan } \\
\text { peternakan kandang terutama pada jenis } \\
\text { peternakan Kambing dan Domba. } \\
\text { - Lokasi pengembalaan memanfaatkan lahan } \\
\text { pertanian basah dan dan lahan pertanian kering. } \\
\text { - Lombok Timur memiliki padang rumput yang } \\
\text { lebih luas dibandingkan wilayah yang lainnya } \\
\text { yang cocok untuk dimanfaatkan sebagai lahan } \\
\text { pengembalaan lepas }\end{array}$ & $\begin{array}{l}\text { - Lahan peternakan seluas } 402.290 \text { ha dikurangi } \\
\text { luasnya sbesar } 181.031 \text { ha. } \\
\text { - Untuk mengurangi sistem pengembalaan lepas } \\
\text { yang dapat merusak lahan pertanian dan } \\
\text { tanaman sebaiknya menerapkan Program } \\
\text { Kandang Komunal. } \\
\text { - Pengembangan peternakan sebaiknya } \\
\text { dipusatkan Lombok Timur yang memiliki } \\
\text { daerah savana yang lebih luas dibanding daerah } \\
\text { lainnya. } \\
\text { - Memindahkan usaha peternakan di luar } \\
\text { kawasan peternakan yang tidak memenuhi } \\
\text { syarat lokasi untuk jenis ternak tertentu ke } \\
\text { tempat yang memenuhi persyaratan } \\
\text { kesesuaian lahannya. }\end{array}$ \\
\hline
\end{tabular}




\begin{tabular}{|c|c|c|}
\hline $\begin{array}{l}\text { Kategori } \\
\text { Lahan }\end{array}$ & Kondisi saat ini & Arahan Pemanfaatan \\
\hline Perikanan & $\begin{array}{l}\text { - Perdagangan disekitar kawasan penangkapan } \\
\text { ikan berpotensi mencemari lingkungan. } \\
\text { - Rusaknya ekosistem terumbu karang oleh } \\
\text { nelayan nakal karena penangkapan ikan } \\
\text { menggunakan bahan peledak dan kimia. } \\
\text { - Pembangunan pelabuhan lintas pulau pada } \\
\text { kawasan penangkapan ikan. } \\
\text { - Kurang tersedianya ruang perumahan dan fasilitas } \\
\text { untuk nelayan serta untuk pengembangan } \\
\text { kegiatan penangkapan ikan. } \\
\text { - Untuk meningkatkan hasil tangkap, masih ada } \\
\text { nelayan yang menangkap ikan menggunakan } \\
\text { bahan kimia dan peledak }\end{array}$ & $\begin{array}{l}\text { - Lahan perikanan seluas } 171.236 \text { ha yang } \\
\text { meliputi perikanan darat dan perikanan laut } \\
\text { perlu ditambahkan lahan seluas } 248.429 \text { ha. } \\
\text { - Menyediakan ruang untuk menampung tenaga } \\
\text { kerja nelayan, berupa pertokoan, jasa, yang } \\
\text { merupakan fasilitas penunjang kegiatan yang } \\
\text { terkait dengan perikanan dan menyediakan } \\
\text { ruang pergudangan untuk pengembangan } \\
\text { kegiatan yang berhubungan dengan tempat } \\
\text { penyimpanan bahan mentah dan barang hasil } \\
\text { produksi. } \\
\text { - Memberikan insentif bagi yang memberikan } \\
\text { dukungan pada aspek perlindungan kawasan. } \\
\text { - Untuk perairan umum perlu diatur jenis dan } \\
\text { alat tangkapnya untuk menjaga kelestarian } \\
\text { terumbu karang. }\end{array}$ \\
\hline Kehutanan & $\begin{array}{l}\text { - Kebutuhan kayu lapis semakin bertambah seiring } \\
\text { dengan semakin bertambahnya kebutuhan akan } \\
\text { lahan terbangun dan kebutuhan bahan bakar } \\
\text { kegiatan oven tembakau. } \\
\text { - Luas hutan semakin berkurang karena terjadinya } \\
\text { pembalakan liar serta pembukaan kawasan hutan } \\
\text { untuk kegiatan pertanian oleh pemerintah untuk } \\
\text { pengembangan kawasan transmigrasi. } \\
\text { - Masih lemahnya penegakan hukum yang } \\
\text { menangani izin penebangan serta mengatasi } \\
\text { kasus pembukaan kawasan hutan dan kegiatan } \\
\text { illegal logging }\end{array}$ & $\begin{array}{l}\text { - Lahan hutan perlu penambahan luasan sebesar } \\
151.439 \text { ha sehingga nilai defisit ekologi sebesar } \\
\text { bernilai surplus. } \\
\text { - Pelarangan pembangunan yang dapat memicu } \\
\text { terjadinya pengembangan bangunan yang } \\
\text { mengurangi luas hutan dan Pembangunan } \\
\text { sarana dan prasarana pada kawasan ini } \\
\text { dibatasi agar tetap lestari. } \\
\text { - Penegakan hukum yang kuat oleh para } \\
\text { pemangku kebijakan dalam memberikan sanksi } \\
\text { yang tegas bagi masyarakat yang melakukan } \\
\text { pembalakan, pembukaan hutan secara ilegal }\end{array}$ \\
\hline $\begin{array}{l}\text { Lahan } \\
\text { Terbangun }\end{array}$ & $\begin{array}{l}\text { - Kegiatan ekonomi, sosial dan industri masyarakat } \\
\text { mendorong semakin tingginya kebutuhan akan } \\
\text { lahan terbangun baik untuk kawasan perkantoran, } \\
\text { pertokoan dan kawasan industri } \\
\text { - Kegiatan pembangunan sering mengkonversi } \\
\text { lahan pertanian serta lemahnya pengawasan } \\
\text { terhadap berbagai pelanggaran tata ruang. } \\
\text { - Kegiatan perdagangan dan jasa yang } \\
\text { memanfaatkan ruang fasilitas umum } \\
\text { menimbulkan limbah serta polusi. }\end{array}$ & $\begin{array}{l}\text { - Lahan terbangun seluas } 87.251 \text { ha perlu } \\
\text { ditambahkan lahan seluas } 159.132 \text { ha. } \\
\text { - Untuk mewujudkan pulau lombok pada tahun } \\
2035 \text { dalam kondisi wilayah surplus } \\
\text { sumberdaya, diperlukan upaya menekan laju } \\
\text { pertumbuhan penduduk hingga } 1 \% \text { serta } \\
\text { menekan standar kebutuhan hidup penduduk } \\
\text { dari 0,78\% turun hingga 0,60-0,50\% per tahun . } \\
\text { - Melakukan evaluasi terhadap inkonsistensi } \\
\text { ruang dilapangan dengan yang tertera dalam } \\
\text { RTRW dalam upaya menekan laju konversi dan } \\
\text { mencegah terjadinya pelanggaran tata ruang. }\end{array}$ \\
\hline $\begin{array}{l}\text { Penyera } \\
\text { Karbon }\end{array}$ & $\begin{array}{l}\text { - Pembukaan lahan dengan sistem pembakaran } \\
\text { merusak vegetasi tutupan lahan dan } \\
\text { menyebabkan polusi. } \\
\text { - Tingginya kebutuhan kayu berimplikasi pada } \\
\text { terjadinya illegal logging dan alih fungsi lahan, } \\
\text { menyebabkan luas tutupan lahan yang berfungsi } \\
\text { menyerap karbon semakin berkurang } \\
\text { - Tingginya aktivitas industri dan pertambangan } \\
\text { serta aktivitas pembakaran oleh masyarakat } \\
\text { menyebabkan semakin tingginya gas-gas } \\
\text { buangan yang harus diserap, sedangkan } \\
\text { kemampuan daya serap membutuhkan waktu } \\
\text { yang lama untuk menyeimbangkan kadar gas-gas } \\
\text { buangan. } \\
\text { - Beberapa jenis tutupan lahan mengalami alih } \\
\text { fungsi lahan }\end{array}$ & $\begin{array}{l}\text { - Lahan seluas } 171.236 \text { ha yang berfungsi } \\
\text { sebagai penyerap karbon perlu ditambahkan } \\
\text { lahan seluas } 14.024 \text { ha. } \\
\text { - Izin pembangunan kegiatan industri harus } \\
\text { semakin diperketat terkait masalah dampak } \\
\text { lingkungan dan setiap kegiatan industri wajib } \\
\text { dikenakan AMDAL. } \\
\text { - Pembangunan sarana dan prasarana industri } \\
\text { yang dapat menimbulkan polutan pada } \\
\text { kawasan ini harus dibatasi agar keseimbangan } \\
\text { daya serap karbon dapat seimbang. } \\
\text { - Pengendalian alih fungsi lahan di dalam } \\
\text { kawasan penyerap karbon. } \\
\text { - Penerapan sanksi yang tegas bagi masyarakat } \\
\text { yang melakukan pembukaan lahan dengan cara } \\
\text { pembakaran lahan }\end{array}$ \\
\hline
\end{tabular}




\section{KESIMPULAN}

Pulau Lombok dikategorikan ke dalam tiga kategori yakni sebagai wilayah sedikit defisit (GFN), wilayah cadangan (berdasarkan kesesuaian dan kemampuan lahan), dan wilayah seimbang (berdasarkan pendekatan terhadap RTRW).

Pendekatan yang paling riil untuk menggambarkan kondisi tapak ekologi Pulau Lombok adalah pendekatan menggunakan RTRW. Pada tahun 2035 jika dihitung menggunakan pendekatan RTRW diperkirakan Pulau Lombok berada pada kategori wilayah defisit. Arahan pemanfaatan ruang berdasarkan nilai tapak ekologi, biokapasitas dan defisit ekologinya adalah: 1) Lahan pertanian seluas 269.568 ha perlu ditambahkan seluas 121.305 ha, 2) Lahan peternakan seluas 402.290 ha dikurangi luasnya sbesar 181.031 ha, 3) Lahan hutan perlu penambahan luasan sebesar 151.439 ha sehingga nilai defisit ekologi sebesar bernilai surplus, 4) Lahan perikanan seluas 171.236 ha yang meliputi perikanan darat dan perikanan laut perlu ditambahkan lahan seluas 248.429 ha, 5) lahan terbangun seluas 87.251 ha perlu ditambahkan lahan seluas 159.132 ha. Untuk mewujudkan pulau lombok pada tahun 2035 dalam kondisi wilayah surplus sumberdaya, diperlukan upaya menekan laju pertumbuhan penduduk hingga $1 \%$ serta menekan standar kebutuhan hidup penduduk dari 0,78\% turun hingga 0,60-0,50\% per tahun agar pasokan sumberdaya masih mampu memenuhi konsumsi masyarakat pada masa yang akan datang. 6) Lahan seluas 171.236 ha yang berfungsi sebagai penyerap karbon perlu ditambahkan lahan seluas 14.024 ha.

Untuk mendapatkan kondisi tapak ekologi yang ideal sebaiknya setiap lima tahun dilakukan perhitungan terhadap kondisi tapak ekologi Pulau Lombok seiring dengan dilakukannya revisi terhadap Rencana Tata Ruang Wilayah sehingga konsumsi berlebihan terhadap sumberdaya yang ada dapat dikendalikan dan dalam rangka pembaharuan data. Selain itu optimalisasi kewenangan dalam penyelenggaraan perizinan pemanfaatan ruang dan penyelenggaraan perizinan pemanfaatan ruang membutuhkan tindakan nyata dari pemerintah daerah Kabupaten Lombok Timur, Lombok Tengah, Lombok Utara, Lombok Barat dan Kodya Mataram yang ada di Pulau Lombok provinsi Nusa Tenggara Barat.

\section{DAFTAR PUSTAKA}

BK Bala, \& Hossain MA. (2012). Modeling of Ecological Footprint and Climate Change Impacts on Food Security of The Hill Tracts of Chittagong in Bangladesh. Journal Environ Model Assessournal, 18, 39-55.

BPS NTB. (2015). Nusa Tenggara Barat Dalam Angka. Mataram: BPS NTB.

Direktorat Jendral Penataan Ruang. (2010). Telapak Ekologis di Indonesia 2010. Jakarta: Kementrian Pekerjaan Umum.

Ewing, B., Moore, D., Goldfinger, S., Oursler, A., Reed, A., \& Wackernagel, M. (2010). Ecological Footprint Atlas 2010. In Gobal Footprint Network (pp. 11-17).

Irawan, B. (2005). Konversi lahan sawah: Potensi Dampak, Pola Pemanfaatannya, dan Faktor Determinan. Jurnal Penelitian Agro Ekonomi, 23, 1-18.

Pasandaran, E. (2006). Alternatif Kebijakan Pengendalian Konversi Lahan Sawah Beririgasi di Indonesia. Jurnal Penelitian Dan Pengembangan Pertanian, 25, 123-129.

Rusli, S., Widiono, S., \& Indriana, H. (2010). Tekanan Penduduk, Overshoot Ekologi Pulau Jawa, dan Masa Pemulihannya. Jurnal Transdisiplin Sosiologi, Komunikasi, Dan Ekologi Manusia, 03(01).

Sekretariat Negara. (2002). Keputusan Menteri Permukima dan Prasarana Wilayah Nomor: 403/KPTS/M/2002 Tentang Pedoman Teknis Pembangunan Rumah Sehat Sederhana Sehat (Rs Sehat).

Sekretariat Negara. (2009). Peraturan Menteri Lingkungan Hidup No. 17 Tahun 2009 tentang Pedoman Penentuan Daya Dukung Lingkungan Hidup. Jakarta: Kementrian Lingkungan Hidup.

Wackernagel, M., Monfreda, C., Moran, D., Wermer, P., Goldfinger, S., Deumling, D., \& Murray, M. (2005). National Footprint and Biocapacity Accounts 2005: The underlying calculation method. In Gobal Footprint Network.

Widiatmaka, 1, * W. A., 2, Sutandi, A., 1, .. 3. (2015). Suitable and available land for cashew ( Anacardium occidentale L .) in the island of Lombok , Indonesia. Journal of Applied Horticulture, 172), 129-139 